\title{
Talent Management and Recruitment Strategies
}

\author{
Kamran Nazari \\ Department of Business Management, Payame Noor University, Iran. \\ Peyman Akbari \\ Department of Business Management, Payame Noor University, Iran.
}

\section{Akbar Veismoradi}

Department of accounting, Payame Noor University, Iran.

\section{Doi:10.5901/mjss.2014.v5n20p3085}

\begin{abstract}
Since the organization of the future will face the challenges of an increasingly competitive, and to manage these challenges require more competent managers and executives today would be more effective, so the talent management becomes more important every day in organizations be enjoyed. The talent management as a system for identifying, hiring, training, promotion and maintenance of talented people, with the aim of optimizing the ability to achieve business results, by definition. Talent management refers to the process in which human talent for key jobs and positions it in the next, identified through a variety of programs of education, be prepared for these occupations. The research presented in this paper, the method was descriptive analytical, that is, a library, and through review. Theses, journals, Latin, Persian, and took advantage of the book, this review recruitment strategies, and identify critical Talents as the initial step in the process is talent management, as well as to assess the benefits and disadvantages Energy issue inside and outside the organization, and approach to the issue of human resources, and tools to identify Talents the organization pays model.
\end{abstract}

Keywords: talent management process, talent management, talent attraction, recruitment strategies

\section{Introduction}

Today, financial and technological resources, many organizations are not the only advantage in having talented and capable individuals who can be considered not only an organization's competitive advantage, but also a lack of resources or other defects, may also be compensated. In the current competitive environment and shifting, and the main feature is its continuous innovation, excellence will be achieved only by organizations that understand the strategic role of human resources, and skilled human resources, knowledge-based merit, are powerful elite (Armestrang, 2008:18) modern economic theory, with emphasis on knowledge-based economy, the most successful economy in the future, know that the economy, producing and distributing knowledge to deal with, and if it the commercial exploitation. thus, in modern economic theories, the role of human capital in the production of knowledge, and earn more and more attention has been (Nunn, 2007:160) by changing the overall competition. In the era of knowledge and wisdom, organizations are increasingly focusing on knowledge and knowledge workers. Therefore, human resources management, the need for a comprehensive process design, talent management are emphasized. To ensure that talent management organizations, qualified personnel with appropriate skills, and job status have (Collings and Mellahi, 2009: 307) is the talent management cycle, which consists of three main areas: to identify and attract talent, retain and retain talent, and talent development. organizations today, do not force others to follow recruiting, but to have talent, something which, as a battle or a war of talent to get talent is remembered (Michaels et a.2001: 11). As, systematic efforts are made to attract customers, attract talent, organizational, methodical action to be accommodated. The best strategy for success in the competition for talent, talent is not the whole collection, but also to attract the best people. In other words, discover, capture, manage, and interact with those who, they participated in the work environment, motivated, committed and efficient. 


\section{The Concept of Talent Management}

The term talent management, the first time in the late 90s, when it was offered, McKinsey researchers found that the actions of the company, has delivered high performance, talent management(Michaels et al, 2001:20), (Reviewed and talent management literature, different definitions of the show. talent management, strategic management of talent flow in an organization. purpose it ensures a good supply of talents, in order to adapt the right people with the right jobs at the right time, based on the strategic goals of the organization (Duttagupt, 2005:2).'s another definition, includes all talent management processes, human resources and technology to manage the affairs. talent management generally means the exploration, discovery, selection, maintenance, development and rehabilitation, employment, and labor force restructuring is (Schweyer 2004: 38),, (talent management, as well as in terms of talent, a lot of writers do not have the same meaning (Aston, \& Morton, 2005). research by CIPD accredited institution study, only $20 \%$ of respondents gave a formal definition of talent management, while $50 \%$ of organizations questioned, being a part of the talent management activities. However, this institution is a complex mix of talent, skills, knowledge, cognitive abilities and potential knows, and talent management to identify and focus on the part of organized labor, which defines high-potential. Talent management facilitate the development and career advancement of people, very talented and skilled in organization, using written instructions, resources, policies and processes are (Guy and others, $2009: 37$ ). talent management, complete set of process for identifying, employing and managing people required to run a successful business strategy of the organization. these processes, which affect the employee life cycle, are divided into three areas: attracting talent, aligning hold talents, and talent development.

1- Identify and attract talent agencies on how people should invest? How to recruitment and hiring, assigned positions, planned? What kind of organization is needed to develop talent? These questions are just some of the questions that, in an organization, when drawing the path of absorption and development of their employees as the most valuable organizational assets should be considered.

2- Emerging talent alignment and functioning of labor must be managed to ensure that the organization continues on the path of its staff, has the highest Productivity. Another issue that must be considered in the process of maintaining talent, compensation system is. Furthermore, the organization needs to be extended to fair compensation policy, it is essential that outputs reports and analyzes the talent and performance evaluation, the system calculates the employee's compensation, should be considered.

3- Developing Talents: The final step of this process, including issues related to learning and development. At this stage, staff need a clear path for career development palpable. In this case, the more investment on employees, with the aim of creating opportunities for learning and development needs to be this way, they have the skills to meet the expectations and needs of the future, is to keep (Tajodin and Maali Tafti, 2008)

\section{Identify and Attract Talent}

The first step in talent management, identifying talented people inside and outside the organization is attracting the elite. Employees in organizations have a variety of personality characteristics and work, and this is a task management abilities and talents, and even the staff identified weaknesses, and to manage them. Head to the individual differences of every individual, as seen eye a factor, and that these abilities and potential, to be used effectively and in the right place. This is a subject that is now under the management of diversity in the world, and also includes talent management, many managers focus on this area, it has attracted (Tajodin and Maali Tafti, 2008). Abolalayi and Qaffari (2006), all employees know the talent and merit, but because of the limitations, argue that organizations should only group of its employees, who have superior talent, and connected with orientations are strategic, long-term investments freely. Results of a survey by Grandz (2009), the 1398 employment of human resources, in over 60 different countries took place, that is the ability to attract and keep new talent, two of the most important problems that managers face today said. Employment responsibilities, the greatest talents are not only time consuming but also require the financial investment, especially if it is related to executive posts. Organizations should develop recruitment strategy, creative and employing traditional methods of recruiting, in attracting new labor to avoid (Phillips \&. Roper, 2009). The planning in this area can reduce many of the costs, and the results are looking good. Identifying talent within the organization, managers will be able to have outstanding talents in order to guide the organization's goals, and to develop and attract talented people from outside the organization, energy and new energy to the organization to injection. This step requires strategies to attract talent to the organization. 


\section{Recruitment Strategies}

Recruitment strategy, which implies that the forces required acquiring and maintaining them effectively and efficiently uses. This strategy is a key part of the process of human resources management

\section{Purposes of Recruitment Strategies}

Keip (1989), the purpose of designing and implementing strategies to recruit, as has the "right to acquire and absorb the forces of competencies, skills, knowledge and potential, have to see the train coming. Methods selection forces that attract the best they can to meet the needs of this group should be considered as the basic activities, and most human resource policies that are designed to nurture and motivate employees, should these activities are based. "The strategic ability of a company to the company's resources in terms of staff depends on the basis and rationale for the recruitment strategies, form. The purpose of this strategy is to ensure that the company can recruit qualified and talented (compared to competitors), to achieve a competitive advantage. These individuals have a variety of skills, and are very experienced and will act so that they have the greatest impact on the success of the organization. Organization of the people, by the applying selection procedures to recruit, and they providing better opportunities and more rewarding compared to other granting agencies, as well as the conclusion of a positive psychological contract, commitment and mutual trust increases, maintenance (Abtahi, 2007).

\section{Human Resource Management Approach to Recruiting}

Human resource management, compared with traditional management staff, the emphasis is more on finding troops of perspectives and behaviors, perceptions and thoughts, and beliefs are more compatible directors. The Tawnelly (1989), are organizations on behavioral characteristics, and views of employees are stressed. The orientation of the organization, has its own risks. Creative organizations and compatible, incompatible forces need to be able to shake the system. If management chooses people according to your taste, this risk is associated with the organization of a series of coordinated turns, and organizational culture will lose its effectiveness. The organization has been successful in the past against the new challenge will not be successful (Tarique \& Schuler, 2010)

\section{Determine the Vacancy before Energy Issue}

Before Energy issue organizations should be given to these questions, if there is a vacancy in the organization? If yes, can the existing staff, to occupy the vacancies? Or how to fill them, the organization turned out to be human? Obviously, the answer to the second question, it is necessary to the organization's policies, and visit the Personnel Unit and any decision on the framework adopted. However, it should be noted that vacancies in the organization predominantly for personal injuries, conscious build. Waste statistics personnel will certainly helped to Energy issue (Saadat, 2006).

\section{Overall Strategy for Recruiting}

Energy issue overall strategy, are of two types: Energy issue within the organization and outside the organization Energy issue.

William Ruth well (2005), six types of domestic breeding strategy within an organization, has stated that they are mentioned briefly below:

1- a strategy based on:

based on this strategy, talented people and alongside prominent people, a special talent or managerial style competitive noting they are. Such talented people involved in the management side of Joe, an authoritarian manager, or someone extraordinary ability, fundamental changes in the start and set up, or things could have been closed, are located.

2- strategy based on the topic:

Based on this strategy, people prone to certain cultured internship, such as managing special projects, committees or missions that require adept person is, try.

3- Time-based strategies:

Based on this strategy, talented people are in pressure to measure their performance. For example, people in 
situations like Emergency meetings, and generally impractical to make important decisions, or to eliminate a competitor from the market are.

4- strategy based on location:

Putting people or places featured in various cultures, and particularly vulnerable people such as dispatch for international job rotation, or send an endemic area for a specific project

5- Strategies based on the change:

In this strategy, susceptible individuals are exposed to a variety of changes, can be placed.

6- Strategies based on strengthening weaknesses:

The purpose of this strategy is to equip talented people working knowledge of different aspects, in terms of where they are weak, like a long job duties (quoting Sam Kan, 2009).

\section{Analysis Benefit and Defects Recruitment Strategies}

Energy issue strategies from within or outside the organization, each with advantages and disadvantages are. Energy issue merits of the organization are to stimulate employees to enhance knowledge, skills and determine their behavior, in order to more jobs in the organization, staff morale and loyalty to the organization, to establish friendly relations between employees and between them and executives, Energy issue reduce costs, recruitment and selection, learning more about the organization of its internal resources, and prevent unsuitable and unfamiliar with the culture and values of the organization. The main disadvantage of this method also prevents the entry of ideas and new people to the organization. It may also lead to hostility and resentment of people, is to upgrade your colleagues. The use of local manpower for taking up posts in fact constitutes investment agencies in the recruitment, selection and training of staff (Saaadat, 2006; Abtahi, 2007; Sam Kan, 2009). Advantages and disadvantages of the Energy issue Outsourcing, the photo above is meant Energy issue benefits from outside the organization, ideas and new people are entering into an organization that sometimes, it works as an infusion of new blood into a patient's body, the weakening of informal relationships the organization, and ultimately increase the quality and quantity of services or goods produced (Abtahi, 2007; Sam Kan 2009). Hired from outside the organization, has the following limitations, which are considered below. These limitations are:

\section{A) cost of external recruitment:}

Almost in most cases, is to hire an outside organization, the organization imposing heavy costs of Be. The first of those is expensive, imported from outside the organization, and the second is that when organizations pay more for an outside force should be attempted, within the legal standards also increase.

B) their morale, and their maintenance problems:

When organizations are hiring from the outside, has a negative impact on morale because people have fewer opportunities for promotion within the organization are, and will be looking for work elsewhere.

\section{C) the slow movement:}

When a company is attempting to hire someone from the outside, it will take time to learn and understand the organization, and then move to the new strategy. During this period, the organization will destabilize.

\section{D) most exposed to external recruitment failures:}

The study, which was conducted in 1997, showed that 40 to 50 percent of hiring external (outside the organization), in the first three years of employment, have failed (Bayham.2002, as quoted by Sam Kan, 2009). anyway, it seems that the decision to hire troops from inside or outside the organization, much depends on the conditions and circumstances of the organization, and the degree of its effectiveness is, for example, if an organization has performance was adequate, and there is no difficulty in reaching the goals of your organization, it may be better that the troops are recruited from within the organization itself. If the organization does not need to have the effectiveness and efficiency, in that case it is better to hire staff from outside agencies (Abtahi, 2007). Important point to be noted here is that talented employees are attracted towards each other, and staff high-potential side are organizations that have an active and talented workforce requirements. One way to capture this talent, providing a competitive advantage above the market, and better than competing firms. Despite the looks, it would be costly, but research has shown that managers were satisfied with the outcome, and the benefits of investing in the best talent, was very satisfactory ( Berger, \& Berger, 2003).

\section{Identify Tools, Talent, Model Agencies}

Organizations that have to be modeled on best practices in talent systems are a variety of tools and techniques to identify 
talent in your organization can use. In most cases, the recognition process by working full-time members of the human resources department, which form a close partnership with line managers (who are responsible for assessments) are cofacilitated. Later in this section, Tools and Techniques that these companies identify their talents, employ, will introduce. "Tool to identify talent first", the company Eli lilly and "Matrix function - the ability to upgrade 2," the company Sonoco used. Other common tools in this case, the results of periodic evaluation of staff performance, and has 360-degree feedback. 360 degree feedback, today one of the main sources of data collection, the evaluation of programs has talent. This tool will ensure that divergent views of managers, subordinates and colleagues in the assessment process, and attention is taken into consideration. Using this feedback, information and a more complete view about the current performance and potential of individuals can provide.

\section{A) tool to identify talent within the company Eli lilly}

The company uses these tools to enable more accurate and reliable assessment of Terry, a talented staff and a more comprehensive list of talented people will provide. This means that, within the company and with the help of an external consultant was designed to evaluate so far, 18 thousand employees of the company, has been used around the world.

This tool talent, a 6-page questionnaire, to collect information about the capabilities and competencies of those uses. This questionnaire is the main criteria considered include:

1) function: performance evaluation of responders, compared with editing capabilities, and the company is evaluated. Assessment of individual performance review of published data, in search of the turning points of the function, and try to analyze it, realize that the person who has the capability.

2) the learning speed in the benchmark:, the desire and ability to learn new skills, especially in harsh conditions, and different variables are evaluated and checked whether the person in question, the first dealing with the situation has succeeded or other new or not.

3) barriers to progress and success: This criterion focuses on the factors that can impede the progress of managing people. For example, if one fails, the desired values and norms, and to bind and obligate the organization to remain approved, would not be promoted in the hierarchy of the organization's management.

\section{B) Matrix function - the ability to upgrade the company Sonoco}

The Company believes the collection of appropriate data, the first step is to identify and manage talent. In the company of all units and departments are asked to provide the following information to the Executive Committee (which is responsible for programs and talent, and succession planning), the ready:

1- Anatomical state employees, the positions of the organization, department or unit where they are.

2- Organizational unit (section)

3- structure, succession planning, corporate shows that potential successors for each post.

4- Matrix function - the ability to upgrade, all staff and all candidates for the succession, in terms of performance, scalability and upgradeability, they are divided into different groups.

Matrix function - the ability to upgrade, which is a matrix of nine houses, the company's employees in terms of performance, and the ability to upgrade to level 3, level 3 , and the total is divided into 9 groups. Each participating departments and units should review their succession candidates, they are assigned to one of nine groups. Information of this type of assessment and classification comes from the different sources. One such resource is the employee's direct personal assessment, based on his observations, and with the results of the employee performance evaluation is done (Abolalayi and Ghaffari, 2006). This matrix is shown in Table 1 (Byars \& Rue, 2008).

Table 1 . Matrix performance - Sonoco Company upgradeability upgradeability

\begin{tabular}{|c|c|c|c|}
\hline 3 & 2 & 1 & \\
\hline $\begin{array}{l}\text { Excellent performance and higher } \\
\text { than expected } \\
\text { - No upgradeability. }\end{array}$ & $\begin{array}{l}\text { - Excellent performance and higher than } \\
\text { expected } \\
\text { - Up to a level is ferments organization. }\end{array}$ & $\begin{array}{l}\text { - High performance and higher than expected } \\
\text { - Fully upgrade within the organization } \\
\text { - Has high potential for managerial }\end{array}$ & 1 \\
\hline $\begin{array}{l}\text { - No upgradeability. } \\
\text { - Good performance and meets the } \\
\text { standards and expectations. }\end{array}$ & $\begin{array}{l}\text { - Function effectively as expected } \\
\text { - The standard works. } \\
\text { - Up to a is ferments level. . }\end{array}$ & $\begin{array}{l}\text { - Fully upgrade within the organization } \\
\text { - Function effectively as expected } \\
\text { - High potential for management }\end{array}$ & 2 \\
\hline $\begin{array}{l}\text { - Notupgradeable. } \\
\text { - Partially meets performance } \\
\text { expectations. } \\
\text { - It is absolutely necessary to improve } \\
\text { performance. }\end{array}$ & $\begin{array}{l}\text { - Maximum upgrade is to a level of } \\
\text { functionality. } \\
\text { - Partially meets performance } \\
\text { expectations } \\
\text { - The need to improve the performance. }\end{array}$ & $\begin{array}{l}\text { - Partially meets performance expectations. } \\
\text { - Rookie of the current work and the need to } \\
\text { improve the performance. } \\
\text { - Potential for improvement. }\end{array}$ & 3 \\
\hline
\end{tabular}




\section{Conclusions and Recommendations}

Talent Management, Human Resource Management is a new approach which involves understanding the value of talented people, and their importance for organizational success in today's competitive environment is. Today, human resource development managers, faced with some serious questions in the context of their work. Questions such as: human resources development field, how can actively and future, to further explore the strategies? How can we best attract and retain talent, and was employed in the service?

One of the misconceptions that sometimes talent management, may be, this is a talent management as an independent process, along with other processes, human resource development to consider. Also, when the topic will focus on talent management, may create the impression that necessarily must select a number of special cases, special services they offer. Overall talent management as a system for identifying, hiring, training, promotion and maintenance of talented people, with the aim of optimizing the ability to achieve business results, by definition, organizations with an investment in talent management hand, a high rate of return to capital, and on the other hand, the collection of talent in your organization will be. In such circumstances, organizations agile and motivated workforce can benefit from the benefits that this will bring to their organizational efficiency. Also, most of the organizations in the current situation, based on the criteria set out regularly, to study and identify potential successors, to pay current and future posts. Today, companies have adequate time to devote to predict current and future needs talent. In addition, globalization and the changing demographics of the workforce, businesses need efficient processes for talent management, has increased.

\section{References}

Abtahi, Hosein (2007), "Human resource management (administration, staff, government agencies, industrial, commercial)," second edition, Karaj: Institute of Management Education and Research .

Abolalayi, Behzad and Ghaffari, Abbas (2006), "Future Leaders: Theoretical and practical experience programs, talent and succession planning managers"; Tehran, Publishing Industrial Management.

Armestrang, M (2008). Strategic human resource management: 4th Edition. London.

Aston, C \& Morton, L. (2005). Managing Talent for Competitive Advantage.Strategic HR Review, 4: pp, 28-31.

Berger, L \& Berger, D. (2003). The Talent Management Handbook, McGraw Hill, Cleveland, OH.

Byars, L \& Rue.W. (2008). Human Resource Management, Published by McGraw-Hill//rwin.9rd.

Collings, D. and Mellahi, K. Strategic Talent Management: A review and research agenda. Human Resource Management Review 19 (2009): 304-313.

Duttagupta, R. (2005): Identifying and managing your assets: Talent management, PricewaterhouseCoopers, London.

Grandz, J. (2007). "Talent Development: The Architecture of a Talent Pipeline that Works", Ivey Business Journal, Vol.70 No.5, pp.1-4.

Guy, Matthew and Sims, Doris (2009) "Future Talent Development, Talent Management and Succession Planning Practical Guide to Husbandry;" Translation: Nasrin Jazani, first edition, Tehran: Saramad.

Michaels, E., Handfield-Jones, H. and Axelrod, B. (2001), The War for Talent, Boston: Harvard Business School Press.

Nunn, Nathan, (2007). "Historical legacies: A model linking Africa's past to its current underdevelopment," Journal of Development Economics, Elsevier, vol. 83 (1), pages 157-175.

Phillips, Deborah R. and Kathy O. Roper, (2009) "A framework for talent management in real estate", Journal of Corporate Real Estate, Vol. 11 Iss: 1, pp.7 - 16.

Saadat Esfandiar (2006), "Human Resource Management", Tehran: Press Samt.

Sam Kan, Sarah (2009), "Readiness Assessment broadcast companies, and refined petroleum products to Iran, planned to implement succession planning, talent management approach", Master Thesis in Educational Administration, University of Allameh Tabatabai.

Schweyer, A. (2004), Talent Management Systems, Best Practices in Solutions for Recruitment, Retention and Workforce Planning, Wiley, New York, NY.

Tajodin, Mohammad and Maali Tafti, Marjan (2008), "Why is talent management?" , Journal of tact, No. 191, pp. 62.

Tarique, I \& Schuler, R.S. (2010). Global Talent Management: Literature Review, Integrative Framework and Suggestions for Futher Research: ScienceDirect Group, Journal of Word Business: 45, pp.122-133.

Tajodin, Mohammad and Maali Tafti, Marjan (2008), "talent management processes, human resource development" Compass Magazine, No. 202, pp. 72. 